Wahyudi Buska, Yogia Prihartini, Ali Muzakir, Abdusshamad; His Thoughts and Movements In The Spread Of Islam In Indonesia.

DOI:10.24014/af.v19.i1.10020

\title{
ABDUSSHAMAD AL-PALEMBANI; HIS THOUGHTS AND MOVEMENTS IN THE SPREAD OF ISLAM IN INDONESIA
}

\author{
Wahyudi Buska \\ Faculty of Civilization and Humanities at The Sulthan Thaha Saifuddin \\ State Islamic University of Jambi \\ wahyudi@uinjambi.ac.id \\ Yogia Prihartini \\ Faculty of Education and Teacher Training at The Sulthan Thaha \\ Saifuddin State Islamic University of Jambi \\ yogia_prihartini@uinjambi.ac.id \\ Ali Muzakir \\ Faculty of Civilization and Humanities at The Sulthan Thaha Saifuddin \\ State Islamic University of Jambi \\ muzakir_adab@uinjambi.ac.id
}

\begin{abstract}
This study aims to find the thoughts and movements carried out by Abdusshamad al-Palimbani. The method used in this research is a literature study or library research, by combining activities related to library data collection methods, reading, collecting, and processing research materials consisting of books, manuscripts, and hand scripts. The findings of this research showed that Abdusshamad al-Palimbani had broad ideas to build Muslim communities, especially in South Sumatra and generally in the archipelago in the areas of Sufism, Tauhid and important to defend the State. In the teachings of Abdusshamad al-Palimbani to his students and the works left behind his mind can be known. His thoughts were collected in various works;(a) HidayatusSalikin fi Suluk Maslak al-Muttaqiin, (b) SiyarusSalikinilalbadatrabb al-alamin (c) Thufah Al-Raghibin fi Bayan Haqiqat Faith Al-Mu'inin, (d). Nasihat alMusliminwaTadzkiratal Mu"minin fi Fadha"il Al-Jihad fi Sabilillah wa Karamat alMujahidin fi Sabilillah (e) Zuhrat al-Murid fi Bayan Kalimat al-Tauhid, (f) Al-Urwat al-WutsqawaSilsilatUli al-Ittiqa, (g) RatibAbdusShamad, (h) Zadd Al-Muttaqin fi TauhidRabb al-,Alamin. The spread of Islam is intended to encourage the community to always fill its days with remembrance and reverence; (a) protect yourself from the fire of hell (b) Allah favors you that God makes us out of those who call on His name, He does not make us blameless (c). be bright and open with the zikrullah light (d). to him the windows of heaven were opened (e). gentle heart and khusyu' (f). abolished it with one sentence from the remembrance of ten crimes.
\end{abstract}

Keywords : Abdusshamad al-Palembani, thoughts, movements, spread of Islam.

\section{INTRODUCTION}

Abdusshamad al-Palembani was a Moslem scholar who was very popular with his works, he was known as aintellectual Moslem who fought hard to attain knowledge, he learned knowledge from various famous teachers, not only from the two holy lands of Mecca and Medina but also almost in several Middle East countries. Abdusshamad alPalembani became a teacher or 
lecturer at Haramain and actively wrote with his various works which are still being studied the pearls of knowledge contained about that. From the many works that have been passed down, it can be seen that there are various scientific disciplines he has dominated, such as SairusSalikin, Hidayatus Salikin, and others.

Abdusshamad al-Palembani was born in Palembang in $1150 \mathrm{H}$ or $1737 \mathrm{AD}$ His father was named AbdurRahman. Seen from other sources, AbdurRahman turned out to be the son of Sheikh Abdul Jalil bin Abdul Wahab bin Ahmad Al AIMahdali, mufti of the Sultanate of Keddah 1710-1782. The life history of Sheikh Abdusshamad alPalembani can be known from several sources, both from his own work in the book "Zuhratul Murid Fi Bayan KalimatitTauhid" or from the work of others (his students) especially from the book Faidhallhsani. In Zuhratul Murid Fi Bayan KalimatitTauhid, this character wrote with his own hand his name, with the sentence: The lowly servant who faqir to Allah Ta'ala namely Abdusshamad bin Abdurrahman Jawi al-Palimbani (Abdusshamad al-Palimbani, 1339 $\mathrm{H}$ : 3). Likewise, in the book of Faidhallhsani written by one of his students, his name is also written: our head and our dignity, namely Sheikh Abdusshamad bin Abdurrahman al-Jawi al-Palimbani (Zen, t.t.:50). Likewise according to Azyumardi Azra the name of this character is Sayyid Abdusshamad bin Abdurrahman al-Jawi al-
Palimbani (Azra, 1994: 245-246).

Abdusshamad al-Palimbani was born in the KutoCerancang Palace environment, one of the Palembang Darussalam Sultanate Palace, located in the 17th and 20th regions of llir now. His father Abdurrahman served as head of the Guards of the Kuto Palace Cerancangan (Zen, 1937: 17). He could not recognize the face of his mother because his mother died at the age of one year, as written in Faidhallhsani: "And it was from until he was a year old then his mother passed away, so he was orphaned in rabbani very easily and please try to maintain it he (Zen, 1937:18).

Abdusshamad al-Palimbani is known as a scholar who has the works of thought in the form of books in large numbers. The subject of his studies is mainly in the field of Sufism. Besides that, Sheikh Abdusshamad also studied the issue of Tauhid and the importance of defending the country. He has a good ability in Arabic, but does not forget the land of his birth, this is indicated by the writing of his work which also uses Malay. The complex ability to study many themes in religious contexts as seen in the writings has demonstrated the aspect of "modernity" of thinking possessed by Syaikh Abdus Sha mad Al-Palimbani.

One of his works, namely the Advice of al-MusliminwaTadzkirat alMu'minin fi Fadha'il Al-Jihad fi Sabilillah wa Karamat al-Mujahidin fi Sabilillah is a book that calls for the importance of jihad against the penetration of the West at that time 


\section{Wahyudi Buska, Yogia Prihartini, Ali Muzakir; Abdusshamad al-Palembani; His Thoughts and Movements in the Spread of Islam in Indonesia \\ DOI:10.24014/af.v19.i1.10020}

he felt himself. But he also stressed the importance of Muslims to wage jihad against the lusts of the fear of death, must be brave to live, to advance the religion of Islam and then also stressed the importance of Jihad Muthlaq namely against opponents of Islam. It is not impossible, the emergence of this thought, has waged Muslim resistance in several Malay countries, including the Fatani area (Pattani) which was oppressed by the Siamese rulers. He is thought to have died fighting the Siamese attack on Kuala Muda (now Pattani in Southern Thailand); which at that time was occupied by Buddhist (Siamese) troops. The death of Sheikh AbdusShamad coincided with the defeat of the Pattani people against Siam in $1832 \mathrm{CE}$, above it was stated that the Sheikh's haul was "on the seventeenth night of the month of Dhu'aidah", based on these data, if he counted the Shahidah in the war of 1832 , then the day of his death is Thursday 17 Dzulqaidah $1247 \mathrm{H}$ together 19 April 1832 AD.

Abdussomad al-Palimbani stu died with famous scholars, not only those in Mecca and Medina, but also in Egypt and Yemen, the student who really struggled with knowledge finally revealed himself as a worldwide figure. Zen in Faidhallhsani explained about the teachers of Abdussomad alPalimbani as follows: And it was the teacher of Sheikh radiallahuanhu that many were well-known of all of them with their advantages and sholeh-sholeh from the cheap
Makkah people and the Medina people who were mawawwarah and the Egyptians who have the knowledge of the fragrant knowledge of the scent of science that is the science of benefits for humans (Zen, 1937: 17).

\section{METHODOLOGIES}

The method used in this research is a literature study or library research, by combining activities related to library data collection methods, reading, collecting, and processing research materials consisting of books, manuscripts, and hand scripts. The findings of this research showed that Abdusshamad al-Palimbani had broad ideas to build Muslim communities, especially in South Sumatra and generally in the archipelago in the areas of Sufism, Tauhid and important to defend the State.

\section{THOUGHTS OF ABDUSSHAMAD AL-PALIMBANI}

From the book "Manakib Fa -idhal Ihsani", some sayings of Sheikh AbdusSomad al-Palimbani to his students and followers. These words contain advice addressed especially to the lovers of the thariqat. The first word consists of three things, namely: (1) the suggestion to always say the truth, (2) give up all charity only to Allah Ta'ala (3) do not delay purifying the heart.

This firstutterance in full reads: "Then half of the words of the radhiallahuanhu" make your clothes stand in all your words, so that he cries out in explaining the members who are zhahir in doing and affirming by you to Allah Ta'ala in all your ages, 
that he hastens in purifying the secret of the heart "(Zen, 1937: 33). To achieve the degree of closeness to Allah, Sufis decorate themselves with some of the most praiseworthy qualities, among them shidq and ikhlash (true and sincere). Abdusshamad al-Palimbani advised to always wear correct and sincere clothing. True in every word and deed, especially true in worship. Greater shidq means not only true in action or speech, but also true in intention, aspiration, promise and truth in maqam or position. . True worship is included in the category of sincerity, for Allah Almighty commands that in worship of Him be done sincerely. While sincerity is the true intention of God. Because shidq and ikhlash are one of the most praiseworthy qualities that are worn by the Sufis. The secondword is a statement of the position of a person who remembers god most. Abdusshamad al-Palimbani says that many people think of him as a guardian of god.As in the word radhialliasahuwaardhahu "and when you see that mankind is growing from the remember (zikrullah) of Allah ta'ala then you know that it is the guardian of Allah ta'ala without a doubt" (Zen, 1937: 33-34). Remembrance of the perceptions of the people is not only centered on verbal remembrance of several levels and amounts to be read, but also a remembrance of the attitude and behavior which always keeps the senses in motion, so as not to be contaminated with anything that is illegal. The Zikrullah reads: (1) la ilahailla Allah, (2) Allah Allah, (3) HU,
HU (4) Haqq, Haqq, Haqq, (5) Hayyun, Hayyun, (6) Qoyyum, Qoyyum, (7) Qohhar, Qohhar (Sairussalikin, p. 12-13). In addition to such commemorations it should also be performed ratib. Ratib is a kind of remembrance or ritual that is practiced regularly upon the completion of the prayer of God 'on Friday night (Zen, 1937: 36)

It can be said that the remembrance made by a guardian of God is a maximal remembrance according to the rules contained in the rules. Third, obey the teacher (Sheikh). Included in Faidhallhsani with the following language: "and half of the word radhiaalhuanhu" begins half of the address of his true disciple and his Sheikh - that is, he left nothing that his teacher could afford. And yet to keep him in his sight and in his back is not to doubt in our hearts the teacher before him and behind him (Zen, 1937: 34). The Sheikh or teacher has an important position in his command not only as a leader who supervises his students in daily life and daily affairs, to avoid deviating and falling into the habit of big and small sin that he must immediately reprove, but he is also a leader. of high spiritual status, and therefore cannot be assigned to a single person, he requires a strict level of intelligence.

According to Abu BakrAtjeh, the Sheikh is a person who has attained to the shrine, a person who is fully immersed in Shari'a knowledge and the fact that through the mosque he has reached a high tomb (Abu BakrAtjeh, 1965: 59). Abdusshamad al-Palimbani said that the Sheikh or 
Wahyudi Buska, Yogia Prihartini, Ali Muzakir; Abdusshamad al-Palembani; His Thoughts and Movements in the Spread of Islam in Indonesia

DOI:10.24014/af.v19.i1.10020

teacher was a successor to the Prophet Muhammad (peace be upon him). it contains all the secrets of the Shari'ah - such as the chronicles of Moses and the Prophet (Abdusshamad al-Palimbani,: tt: 16).

The fourth word about the priority of the followers of alPalimbani (closest to Samaniyah) is: "And he said that I confess to those who obeyed our commands that this was true, believing that entering Allah Ta'ala would bring him into heaven. Beginning our command is the wall from the fire of hell and its bounders "(Zen, 1937: 34). The word al-Palimbani has something in common with what his teacher Sheikh Muhammad Samman said about the priorities of the followers of Sammaniyah, as it is written in the Muhammadan Qur'an al-Samman alMadani's Evening Message even in different words or languages: "And half from the words of Sheikh Muhammad Sammanr.a that whoever eats our food is Allah's remembrance then he will go to heaven and whoever enters our house or violates us forgives Allah Ta'ala all his sins so he said (alPalimbani, 1331: 9)

The fifth word is a drink that cools the soul, is a symbolic expression that drinks water that can quench its thirst, and is that it says "dare you to protect yourself from the aura then it is a clear drink" (Zen, 1937: 34). If the disciple (Abdusshamad al-Palimbani) uses the symbolic expression of the word "clear drink" to describe the remembrance of remembrance or witchcraft in the Samaritan order, the
Master (Sheikh Muhammad Samman) uses the symbolic expression with the words " Food, "as stated in the Sheikh Muhammad Samman's Manuscripts above. The word "food" is also interpreted as a remembrance formula taught in the Sammaniyah (Zulkifli, 2001: 52)

The sixth word. His advice is to use the world as a gateway to the afterlife, because the world is a gift from God that is to be commended. And it says, "Do not divide the world, for it is from the great gift of Allah Ta'ala, if there is no world to read there is no hereafter" (Zen, 1937: 35). It is interesting to note al-Palimbani's opinion of the world, since in the public perception of the Sufis are those who leave the world or hate the world. That perception is misunderstood, especially when looking at alPalimbani's words above. His words are closely related to his views on Sufism.

His seventh word was to study the scriptures relating to the world of Sufism authored by Sufis. The expression is as follows: And it says: "Make clear to you the aboriginal books of the aborigines, and then he is beyond all knowledge and beyond the reach of the eyes and the eyes (Zen, 1937: 36).

The eighth word covers many things, namely: (1) receiving knowledge from anyone who can draw close to Allah Ta'ala, as long as they believe in the truth, (2) ease the path to Allah SWT, (3) pay attention to manners orders. (Zen, 1937: 36).

\section{ABDUSSHAMAD AL-PALIMBANI'S MOVEMENT IN THE SPREAD OF ISLAM}


The movement in the spread of Islam by Abdusshamad alPalimbani consisted of (1) an invitation to have good character, namely: sincere worship only for God, telling the truth and purifying the heart (2) invitation to increase remembrance (3) invitation to respect teachers (4) an invitation to be a person who practices the Thariqat(5) invitations to do wirid (6) invitations to utilize the world for the afterlife (6) invitations to learn Sufism (7) invitations to accept truths that can draw closer to God and invitations to pay attention to etiquette in the thariqat. First. Worship with sincerity is a condition of accepting the charity of a servant. There are three degrees of sincerity. (a) worship performed solely to achieve God's pleasure, not expecting heaven, nor for fear of the torments of hell (b) worship performed for seeking reward and heaven or fearing from His torment. (c) worship performed because of wanting glory.

The first is the highest degree of ikhlash, the second is the middle degree of sincerity, the third is the lowest degree. While apart from the three degrees are riya' and sum'ah (showing off good deeds and there is an interest to be famous. Sidhq or telling the truth and purifying the heart remains related with ikhlash, because sincerity in worship is difficult if humans do not have Shidq and clean nature.Therefore, the character to God in the form of sincerity in charity is very important to be the purpose of da'wah. Secondly, it invites humans to multiply dhikr. Basically dhikr is expected to produce spiritual clarity in a person, so that it affects the attitude and behavior. Thereare several effects that can be caused, namely: 1 . Soften a person's heart so that he tends to accept and follow the instructions (guidance) 2. Awaken awareness that God is the regulator 3. Improve the quality of worship 4. Maintain yourself from the temptations of the devil 5 . Keep it from doing ma'siat (Arsam, 2012: 115)

It can be understood that the impact of the effect of remembrance by a person is part of the purpose of preaching because it invites humans to always remember their Creator, so that their behavior is organized according to the behavior of those who are pious. Third, inviting humans to have manners towards their teacher. In the book "HidayatushShalihin" written by Abdusshamad al-Palimbani explained there were eleven manners which a student must have. Among them are giving greetings, asking permission when asking, don't look left and right when sitting in front of the teacher, and when the teacher is standing, he also stands up. (Abdusomad al-Palimbani, 2006: 171)Fourth, da'wah is intended to invite mad'u to follow the tarekat, especially the Samaniyahthariqat. Thariqat is a way, instructions in doing something of worship according to prescribed teachings, exemplified by the Prophet Muhammad shollalahu alayhi-wasallam and done by friends and tabi'in, hereditary to the teachers, connect and connect chains. Teachers who provide guidance and guidance are usually called murshid. All guidance given by a teacher to his 
Wahyudi Buska, Yogia Prihartini, Ali Muzakir; Abdusshamad al-Palembani; His Thoughts and Movements in the Spread of Islam in Indonesia

DOI:10.24014/af.v19.i1.10020

students in matters of worship is called thariqat. The important thing between the practical guidance is matters relating to remembrance and procedures. The Samaniyah Order is a thariqat that was given to Muhammad Samman. A famous tarekat teacher in Medina. His remembrance is known by the name of RatibSaman (AboebakarAtjeh, 1966: 338-340).

Ratib Saman begins by chanting the name of Allah, the Most Gracious and Merciful,"Bismillahirra hmanirrahim" followed by the saying of forgiveness asking Allahswt for forgiveness. Then, recitation of surah al-Fatihah addressed to the propphet Rasulullah shollallahualayhi wasallam, recitation of sholawat delivered to Rasulullah, to all the prophets and Apostles, to the angels, to the servants of Allah that Sholih from the inhabitants of heaven and earth.Furthermore, an expression of prayer was given to God to give pleasure to the companions of the prophet sayyidina Abu Bakr ashshiddiq, sayyidina Umar bin Khattab, sayyidinaUsman bin Affan and sayyidina Ali bin AbiTalib and prayers for all the Companions of the Prophet. Doing the RatibSaman continues with the pronunciation of the phrase TawheedLaallaahallallah with different styles as much as 300 times. Followed by (1) recitation of the Holy Qur'an at-taubah 128-129 (2) Recitation of sholawat and greetings to the Messenger of Allah 3 times. (3) Recitation of du'a (praying) (4) Recitation of Surah al-Fatihah to the Messenger of Allah, families, friends, wives, family experts, all the 150
Prophets and Apostles of the martyrs', servants of God who are pious, father of the Prophet Adam as, mother of Eve, Prophet Hidhir of the Prophet llyas, sayyidina Abdullah bin Abbas waushuulihim wafuruu'ihi $m$ waahlisilsilatihim wal aakhidziina‘ anhumsyaiul lillahilahumulFaatihah.

Al-Fatihah is further addressed to al-muqoddam Muhammad ibni Ali Ba Alawi and to all Sufi teachers from West to East, specifically to Sheikh Abdul QadirJailani to Sayyidi Sheikh Junaidi al-Baghdadi, and also to Sufi teachers from the Qadiriyah order. Naqsya-bandiyah, Kholwatiyah, 'Aidurisiyah, Alawiyah.Al-Haddadiyah, as-Saqofiyah as well as for all zuriyat Sayyidina Muhammad shollallahu alayhi wasallam.Also al-fatihah is directed to the spirit of the four priests waushuulihimwafuru'ihimwaah lisilsilatihimwalaakhidziinaanhumsyaiul lillahilahumulfatihah The next reading of al-Fatihah is also addressed to Quthbil Akwan Mahbub al-Rahman Shaykh Muhammad Samman, as well as prominent Ghazabad priests, Imam Sanusi, IbnHajar, Imam Ramli, Imam Rafii, ImamAbuHasan al-Adsy'ari, Abu Mansur al- Maturidy, Khatib Syarbaini waushuulihim wafuruuihim waahlisils ilatihim walaakhidziina anhum syaiu I lillahilahumul fatihah.

Al-Fatihah was later addressed to Sheikh Abdussomad al-Palimbani after it was first read to his disciples. To all Muslimins and Muslimats, the present and the unseen, the pilgrims and the Moslems and for the Messenger of Allah shollallahu alai hi wasallam and for his whole family and his companions, the Prophet Muhammad (peace be upon him). -48) 
doing RatibSaman concludes with a prayer reading. Like the other commandments, the Samaniyah's teachings through their remembrance are able to draw people closer to God and distance themselves from evil behavior. Fifth, the spread of Islam is intended to encourage the community to always fill its days with remembrance and reverence;(a) protect yourself from the fire of hell (b) Allah favors you that God makes us out of those who call on His name, He does not make us blameless (c). be bright and open with the zikrullah light (d). to him the windows of heaven were opened (e). gentle heart and khusyu'(f). abolished it with one sentence from the remembrance of ten crimes. (Abdussomad al- Palimbani, 2006: 105-106). Sixth, invite people to be careful of the world. In a hadith qudsithere is a parable about the world: "Allah has revealed to David as with his word: O David: the parable of the world is like a carcass where dogs gather around him, dragging him everywhere. Are you happy to be a dog, then come along to drag the carcass here and there? O David! Be gentle in conversation and be modest in your dress. The fame of your name among the public will not be identical forever (with that which is obtained) in the hereafter (Ali Usman.et al, 1975: 213). The spread of Islam is aimed at reminding people that do not be like dogs fighting over rotten carcasses, making the world a destination in life. Opponents of a detestable world are world lives that will give good results in the hereafter by paying attention to
Allah's laws. The world is a means given by God to humans to achieve happiness in the afterlife. To achieve happiness one needs to have a correct understanding of the world. That is why you need to be reminded of your duty in this world to serve God not the world. Seventh, studying Sufism.The purpose of da'wah according to Sheikh Abdusshamad alPalimbani is to invite people to learn Sufism, because studying Sufism is legal fardhu 'ain. According to Sayyid Abdul Qadir Ali Idrus in the book called "ad-Daaru as-Tsamin" as quoted by Abdusshamad al-Palimbani in Hidayatus Shalihin;all the knowledge that he is required to fard 'ain is three matters: first, the knowledge of monotheism will be called usululuddin's knowledge. Second, the science of syara 'which is called he will be the science of jurisprudence (ilmufigh). The three inner sciences will be called Sufism. As for qadarfardhu 'ain in the science of psychology or the knowledge of Sufism, that is knowing everything that will save so that the deeds he does not become corrupted, such as knowing something that can cancel the reward of his prayer, the reward of his fast and so on. (Abdusshamad alPalimbani, 2006: 5). Abdusshamad alPalimbani also argued that if someone wants to win in the world and in the hereafter then his life should be spent studying Sufism, practicing "muthola'ah" he will learn Sufism, because so much fear of Allah. (Abdusshamad alPalimbani,2006:4). Eigth, the purpose of da'wah is to introduce civilization in the match. In everyday life there are some manners 
Wahyudi Buska, Yogia Prihartini, Ali Muzakir; Abdusshamad al-Palembani; His Thoughts and Movements in the Spread of Islam in Indonesia

DOI:10.24014/af.v19.i1.10020

that need attention: (1) always improve his morals, by keeping his words (2) showing respect for people who sit with him (3) always maintaining silaturrahim (4) maintaining family honor (5) When going to sleep, he cleans his body first, lying on top right side while doing zikrullah to Allahswt until he falls asleep (6) when he wakes up he is grateful and praying (7) To wake up at midnight during the midnight prayer he should: reduce his food, reduce his drinking, always do good every day, stay away from cursing people, lie, talk about something that is not useful, keep his eyes and limbs from being unclean (8) wake up with unclean the feeling of fear immediately performs "wudhu" praying and praying earnestly while asking Allah's forgiveness. (9) he must also pay attention to manners to enter the bathroom (10) arrange his food and drink with due regard to all the laws of sharia.(Abu BakarAtjeh, 1966: 206-207).

\section{CONCLUSION}

Abdushamad al-Palimbani was a prolific scholar who produced many works consisting of books and treatises in either Arabic or Malay. which until now still be studied both in the country of origin up to Abroad. AbdusSomad al-Palimbani had very bright thoughts. These thoughts contain advice aimed primarily at the lovers of the tarekat. The first word consists of three things, they are: (1) encouragement to always say the truth, (2) let all charity go to Allah Ta'ala (3) do not delay purifying the heart.The movement in the spread of Islam by Abdusshamad al-Palimbani consisted of (a) an invitation to have good character, namely: sincere worship only for God, telling the truth and purifying the heart (b) invitation to increase remembrance (c) invitation to respect teachers (d) invitation to be a person who practices the tariqah (e) invitation to do wirid-wirid (f) invitation to use the world for the afterlife ( $g$ ) invitation to learn Sufism (h) invitation to accept the truth that can draw closer to God and invitation to pay attention to manners in the thariqat.In the Sufistic world Abdusshamad alPalimbani advocated; first, to always wear true and sincere clothing. True in every word and deed, especially true in worship.Second, it is a statement about the position of someone who has a lot of remembrance to Allah. Abdussomad al-Palimbani said that the person who does a lot of remembrance is a guardian of Allah. Third, obedience to the teacher (sheikh). Fourth, about the virtues of followers of the al-Palimbani order (ThariqatSamaniyah). Fifth, about drinks that soothe the soul, symbolic expressions that drink water that can release his thirst, and is he said "dare to yourself by preserving from aurat then that he is a clear drink. 


\section{REFERENCES}

Abdullah, Taufik (ed.). 1987. Sejarah dan Masyarakat; Lintasan Historis Islam di Indonesia. Jakarta, Pustaka Firdaus.

Abdullah, Mal’an. 2012.Jejak Sejarah AbdusSamad al-Palimbani. Palembang, SRF Press.

Al-Palembani, Abdushamad.2006. Hidayatus Salikin; Mengarungi Samudera Ma'rifat .Surabaya, Pustaka Hikmah Perdana.

Al-Palimbani, Abdusshamad. 2006. Hidayatus Solihin, Surabaya, Haramain Jaya.

Al-Palimbani,Abdussomad, Sairus Salikin, Indonesia, daarlhya; Kutub al-arabiyyah,tt

Arsam, Arsam. "Peran Orang Tua DalamMembangun Kepribadian Anak."Komunika: Jurnal Dakwah dan Komunikasi 6, no. 1 (2012).

Azra, Azyumardi. 1994 Jaringan Ulama Timur Tengah dan Kepulauan Nusantara Abad XVIII, Bandung.Mizan

Azra, Azyumardi. 1995. Jaringan Ulama Timur Tengah dan Kepulauan Nusantara Abad XVII dan XVIII; Melacak Akar-Akar Pembaruan Islam di Indonesia. Bandung, Mizan.

Azra, Azyumardi. 1999. Renaisans Islam Asia Tenggara; Sejarah Wacana dan Kekuasaan, Bandung, Remaja Rosdakarya.

Buska W., Prihartini Y.,Pendidikan Sebagai Proses Transmisi Sosial Budaya.NAZHARAT; Jurnal Kebudayaan.24 (01).2019, 37-52 Buska, W., Prihartini, Y., Yusuf, M. and Muhammad, R.D., 2020, May. Islamic Values in Speech Roll Tradition as Humanist Education in Jambi.In 4th Asian Education Symposium (AES 2019) (pp. 159-163). Atlantis Press.

Atjeh, Abu Bakar. 1966. Pengantar Ilmu Tarekat: Uraian Tentang Mistik, Jakarta: Fa.H.M.Tawi Son Bag.

Chatib,Quzwain. 1984. Mengenal Allah: Studi Mengenai Ajaran Tasawuf Syaikh Abdusshamad alPalimbani, Jakarta: Bulan Bintang Choiriyah, C. 2017. Pemikiran Syeikh Abdussomad Al-Palimbani Dalam Kitab Faidhallhsani (Tinjauan Terhadap Tujuan Dakwah).

Ghaidan: Jurnal Bimbingan Konseling Islam dan Kemasyarakatan, 1(1), 41-59.

Departemen Agama RI, 1989. AlQur'an Dan Terjemahnya, Semarang, CV.Toha Putra

Mahmud, Kiagus Imran. 2008. Sejarah Palembang. Palembang, Penerbit Anggrek.

Nasution, Harun. 2008. Islam Ditinjau dari Berbagai Aspeknya Jilid II. Jakarta, UI Press

Pramasto, A. 2020.Kontribusi Syaikh AbdusShamad Al-Palimbani pada Aspek Intelektual Islam di Nusantara Abad ke-18.Tsaqofah danTarikh:Jurnal Kebudayaan dan Sejarah Islam, 4(2), 95-106.

Prihatini Y, Buska W. Pembelajaran Berbasis Sosial Dan Budaya. NAZHARAT; Jurnal Kebudayaan.25 (02). 2019, 118134 
Al-Fikra: Jurnal Ilmiah Keislaman, Vol. 19, No. 1, Januari - Juni, 2020 (144 -154)

DOI:10.24014/af.v19.i1.10020

Rahman, Budhy Munawar. 2006. IAIN Raden Fatah

Ensiklopedi Nurcholish Madjid (edisi digital). Bandung, Mizan.

Sanusi, Salahuddin. 1962,

Pembahasan Sekitar PrinsipPrinsip Dakwah Islam, tp

Shihab.Alwi. 2001 Islam Sufistik, Jakarta:Mizan,

Syarifuddin, Andi. 2010. Ratib Samman; Riwayat, Fadhilat, dan Silsilahnya. Palembang, Penerbit Anggrek.

Syarifuddin, Andi. 2012. Manaqib Syekh Muhammad Samman alMadani.Terj.Melayu olehSyekh Muhammad Azhari alPalembani. Palembang, Zuriat Datuk Azhari.

Syukir, Sanusi,tt., Dasar-Dasar Strategi Dakwah Islam, Surabaya, al-Ikhlash

Shihab, Alwi. 2009. Akar Tasawuf di Indonesia, Depok, Pustaka liman.

Simuh. 2002. Tasawuf dan Perkembangannya dalam Islam. Jakarta, Raja Grafindo Persada.

Usman, Ali KHM, 1994, Hadist Qudsi, Bandung, CV Diponegoro

Wahyudi, 2019.Naskah Muqaddimah al Mubtadin, Jakarta: Perpustakaan Nasional Republik Indonesia

Zawawil zhom, Abdullah Wirid da Dzikir, tp, $1434 \mathrm{H}$.

Zen, Kgs, Faidhallhsan, 1937, tidak diterbitkan.

Zulkifli, 2001.Kekeramatan dan pemikiran Syeikh Muhammad Samman: Kajian isi Teks Beberapa Kitab Manaqib Samman,Laporan Penelitian, Palembang, Pusat Penelitian 